\title{
Value of Supplementary Feeding for Lactating Cows Grazing Fertilized Grass Pastures in Puerto Rico ${ }^{1}$
}

\author{
R. E. McDowell, H. Cestero, J. D. Rivera-Anaya, M. Soldevila, F. \\ Román-García, and J. A. Arroyo-Aguilú ${ }^{2}$
}

\begin{abstract}
There were 282 cows that completed one or more lactations on grazing alone $\left(T_{1}\right)$; or grazing plus supplements of molasses $\left(T_{2}\right)$, ground corn $\left(T_{3}\right)$, high concentrate feeding $\left(T_{4}\right)$, limited concentrate feeding $\left(T_{5}\right)$, and urea + molasses $\left(T_{6}\right)$. Supplements for $T_{2}, T_{3}, T_{5}$, and $T_{6}$ were fed at the rate of $1 \mathrm{lb} / 2$ $\mathrm{lb}$ of milk in excess of $22 \mathrm{lb} /$ day and for $T_{4}$ at the rate of $1 \mathrm{lb}$ of concentrate per $2 \mathrm{lb}$ of milk irrespective of level of production. Stocking rate was one cow per acre for all groups on highly fertilized pastures of star, pangola or guineagrasses in a humid area of Puerto Rico. During the dry period all cows were on grazing alone. Calvings were for the period October 1969 to February 1974. Temperature conditions and rainfall were adequate for growth of grass throughout the year.

Average milk and fat yields, using age-month of calving adjusted records, were: 6,912 and $245 ; 8,005$ and $275 ; 8,080$ and $284 ; 9,861$ and $335 ; 9,300$ and 315 ; and 8,424 and $286 \mathrm{lb}$ for $T_{1}, T_{2}, T_{3}, T_{4}, T_{5}$, and $T_{6}$, respectively. Treatment effects were significant $(P<.05)$ for lactation length, milk and fat yields, and final body weight but were not significant for fat percent, gain in body weight, or measures of breeding efficiency. There was no association between initial body weight and treatments.

Breeding efficiency, determined as time from parturition to first estrus, and calving interval were below average on grazing alone $\left(T_{1}\right)$ and high supplement $\left(T_{4}\right)$. When milk yields were adjusted to expected yield per cow per year, the gains over grazing alone were $20.2,21.4,42.0,39.0$, and $33.3 \%$ for $T_{2}, T_{3}, T_{4}, T_{5}$, and $T_{6}$, respectively. From these results medium, but not high, levels of supplementary feeding of lactating cows on high quality tropical grass pastures are economically feasible.
\end{abstract}

\section{INTRODUCTION}

The value of supplementary feeding, either lactating cows or fattening cattle, while grazing high quality pastures is subject to conjecture both from the standpoint of performance and economics. This appears to be the case irrespective of prevailing climatic conditions. From experiments conducted in both tropical and temperate areas, there is general agreement that low levels of supplementary feeding (3 to $5 \mathrm{lb} /$ day of concentrates) are insufficient to bring about a significant increase in total lactation milk yields $(4,5,6,7,9,14,18,19)$. However, supplementation at a ratio of $1 \mathrm{lb}$ of concentrate to 1,2 , or $3 \mathrm{lb}$ of milk increased

${ }^{1}$ Manuscript submitted to Editorial Board June 12, 1975.

${ }^{2}$ Consultant, University of Puerto Rico and Professor, Department of Animal Science, Cornell University, Ithaca, N.Y.; Associate Animal Husbandman; former Director; Associate Nutritionist; Research Assistant; and Associate Nutritionist, Department of Animal Husbandry, Agricultural Experiment Station, Mayagüez Campus, University of Puerto Rico, Río Piedras, P.R. 
yields significantly $(5,6,17)$. The conclusion from most of the experiments has been that the cost of the supplement exceeds the value of increased gains in milk yield. McDowell et al. (13) and Thurbon et al. (17) agree in part but contend that some systems of supplementation are economically feasible.

From a review of experiences on modest to high levels of supplementary feeding for fattening cattle on tropical pastures, McDowell and Hernández-Urdaneta (12) concluded that, except as an emergency measure or to increase the carrying capacity of natural grassland pastures, the cost of the supplement exceeded the value of increased weight gains. They also conluded that supplementation on excellent pastures increases animal gains significantly, but the practice is not economical since 40 to $50 \mathrm{lb}$ of supplement are required for each additional pound of gain in excess of that made by unsupplemented animals.

The majority of the experimental investigations on supplementary feeding of lactating cows encompassed short periods of time, both in numbers of years and time of feeding ( 2 to 12 weeks) and rather limited numbers of animals per treatment, usually less than 10 .

The objective of the present experiment was to simulate practical farm conditions in determining: a) the value of supplementary feeding compared to grazing alone; b) the influence of type of supplement on performance; and c) the influence of supplement on correlated traits, such as weight gain, breeding efficiency, and health problems.

\section{MATERIALS AND METHODS}

The investigations were conducted over a 5-year period (October 1969 through September 1974) at the Gurabo Substation (longitude 66 $6^{\circ} 12^{\prime}$ W and latitude $18^{\circ} 16^{\prime} \mathrm{N}$ ), located approximately $25 \mathrm{mi}$ southeast of San Juan. The elevation is $78 \mathrm{ft}$ and the climate warm and humid. The annual maximum temperature is $86^{\circ} \mathrm{F}$ with monthly means of $82^{\circ}$ in January to $89^{\circ} \mathrm{F}$ in July to September. Minimum temperature is $66^{\circ} \mathrm{F}$ with monthly means from $59^{\circ}$ to $71^{\circ} \mathrm{F}$. The average wet bulb temperature is $75^{\circ} \mathrm{F}$ with monthly variations from $59^{\circ}$ to $71^{\circ} \mathrm{F}$. The annual rainfall is 76 in from a low in February of 2.5 in to a high of 8.2 in July. An earlier report (13) gives further details on climatic conditions and a preliminary evaluation of four of the feeding regimes.

\section{FEEDING REGIMES}

There were six feeding regimes designated as follows:

$\mathrm{T}_{1}$ - grazing alone;

$\mathrm{T}_{2}$ - grazing $+1 \mathrm{lb}$ of molasses per $2 \mathrm{lb}$ of milk in excess of $22 \mathrm{lb} /$ day;

$\mathrm{T}_{3}$-grazing $+1 \mathrm{lb}$ of corn per $2 \mathrm{lb}$ of milk in excess of $22 \mathrm{lb} /$ day; 
$\mathrm{T}_{4}$ - grazing $+1 \mathrm{lb}$ of commercial concentrate mix ( $20 \%$ crude protein, $72.5 \% \mathrm{TDN}$ ) per $2 \mathrm{lb}$ of milk irrespective of level of daily yield;

$\mathrm{T}_{5}$-grazing $+1 \mathrm{lb}$ of the commercial concentrate per $2 \mathrm{lb}$ of milk in excess of $22 \mathrm{lb} /$ day; and

$\mathrm{T}_{6}$-grazing $+1 \mathrm{lb}$ of urea $(4 \%)+$ molasses per $2 \mathrm{lb}$ of milk in excess of $22 \mathrm{lb} /$ day.

The cows were on pasture at all times except for milking twice per day and feeding. Those scheduled for supplementary feeding were stanchioned and fed individually before milking with quantity of supplement adjusted according to milk yield at 10-day intervals. Refused feed was recorded for each feeding. A mixture of 1:1 common salt and dicalcium phosphate was available in the holding area adjacent to the milking parlor.

For all regimes the cows grazed together at a stocking rate of one cow per acre. During the dry period the cows remained on the same pastures without supplement.

The pastures consisted entirely of grasses, principally Pangola (Digitaria decumbens), intermixed with Star (Cynodon nlemfuensis), Para (Brachiaria mutica) and some native species. Fertilizer, 15-5-10, was applied at the rate of 1 ton/acre yearly in four applications. Cows on all feeding regimes grazed as a single group for 2 to 4 days per pasture. Each pasture had a rest period of at least 21 days. Climatic conditions, laboratory evaluation of the grazing, and other features of the experiment were described in an earlier report (13).

\section{ANIMALS AND RECORDS}

Beginning in October 1969, all cows and heifers calving in the herd at the Gurabo Substation were assigned to a treatment group according to body weight, predicted milk yield, and breed group. There were 282 cows with 433 calvings that completed 389 satisfactory lactations on one or more of the treatments. The initial assignments of cows was for two lactations per treatment. After completing two lactations, cows were shifted to new groups for balance of numbers or to initiate other treatments. The herd consisted of about $65 \%$ high grade or purebred Holsteins, 25\% Brown Swiss, and 10\% crossbreds.

Lactations were 300 days in length or until daily yield declined to less than $10 \mathrm{lb} /$ day on twice-a-day milking. Cows or heifers which did not produce at least $700 \mathrm{lb}$ of milk in the first 30 days were removed for low production. All observed estruses were recorded. Breeding by artificial insemination commenced at the first estrus following 60 days postpartum. Those cows not pregnant by 300 days postpartum were culled. Observations of health problems and veterinary treatments were recorded. Body weights were taken on the day of parturition (initial weight), at monthly intervals during lactation, and on the last day of 
lactation (final weight). Weight gains or losses were differences between the initial and final weights.

\section{METHODS OF ANALYSIS}

All records considered satisfactory for calvings from October 1969 to February 1974 (53 months) were used for determining treatment effects. These included both actual and projected records. Actual records were up to 300 days without noted abnormalities. Projected records were substituted where identified health problems caused a change in daily milk yield of $25 \%$ or more for 3 or more days and it was evident the disturbance influenced yields for 10 days or more. If serious disturbances occurred in the first 30 days, the record was deleted. When the point of disturbance occurred after 30 days, the record was projected from the last normal day to a 300-day basis using standard DHIA factors (11) and substituted for the actual record. Of the total records $14 \%$ were substitutions for actual records.

Since calvings for all treatments were not common to all years, a twoway classification model for years and treatments was not used for the entire set of data. However, this type model was used twice where subclasses were filled to determine year effects on milk yield, fat yield, fat percent, and days in lactation. When the year effects were random and treatment effects were fixed, year and the interaction effects were not significant for any of the traits, but treatment effects were significant at the $1 \%$ level for all except fat percent.

A three-way analysis of variance was used to determine the effects of age, months of calving, and treatment. Age and month of calving effects were significant at the 5\% level. After adjustment for age-month of calving using factors derived from DHIA records in Puerto Rico (2), the $F$-values for age and season became nonsignificant. Sires of cows and breed group were ignored since sire and breed groups were assumed randomly distributed among treatments.

Since year, month of calving, and age were either nonsignificant or adjustments were made, a one-way analysis of variance model with treatment effects fixed was appropriate to determine treatment effects for each trait. Age-month of calving adjusted records were used for milk and fat yields, while actual values were used for body weight, fat percent, and measures of breeding efficiency.

Scheffe's criterion (15) was used to separate treatments differing significantly.

\section{RESULTS AND DISCUSSION}

\section{LACTATION LENGTH AND PRODUCTION}

Treatment differences were significant for lactation length (table 1). Cows on grazing alone $\left(\mathrm{T}_{1}\right)$ and those supplemented with molasses $\left(\mathrm{T}_{2}\right)$ 
TABLE 1. - Mean squares and F-value from analysis of variance and test of significance for

\begin{tabular}{lrrr} 
& \multicolumn{2}{c}{ various measures } & \\
\cline { 2 - 3 } & \multicolumn{2}{c}{ Mean Squares } & F-value \\
\cline { 2 - 3 } & Treatment & Eror & \\
\hline d.f. & 5 & 386 & \\
Lactation length & 1371.3 & 298.1 & $4.6^{* 1}$ \\
Milk yield & 88976576.0 & 3120716.0 & $28.5^{* * 2}$ \\
Fat yield & 82083.1 & 3828.1 & $21.4^{* *}$ \\
Fat \% & .3 & .1 & 2.8 \\
Body weight & & & \\
Initial & 59392.0 & 40490.4 & 1.4 \\
Final & 80896.0 & 12291.9 & $6.6^{*}$ \\
$\quad$ Gain & 28468.7 & 31909.1 & 9 \\
Breeding & & & .9 \\
$\quad$ Calving to first heat & 1277.4 & 1475.4 & .9 \\
First breeding to conception & 9746.8 & 4924.4 & 1.9 \\
Calving interval & 5292.8 & 2895.4 & 1.8 \\
Services/conception & 5.4 & 2.4 & 2.2 \\
\hline
\end{tabular}

${ }^{1} 5 \%$ level.

$21 \%$ level.

or corn $\left(\mathrm{T}_{3}\right)$ tended to have shorter lactations than cows supplemented with urea + molasses $\left(\mathrm{T}_{6}\right)$ or commercial concentrates $\left(\mathrm{T}_{4}, \mathrm{~T}_{5}\right)$ (table 2$)$. For $\mathrm{T}_{1}, \mathrm{~T}_{2}$, and $\mathrm{T}_{3}, 37$ to $44 \%$ of the records terminated due to drying off were less than 300 days in duration; whereas, the frequencies for short lactations were only 20 to $30 \%$ in the other three groups. Based on level of supplement fed, cows in $\mathrm{T}_{6}$ milked longer than expected. This may be due to number of cows and to a higher proportion of second or later lactation cows. According to Scheffe's criterion, the differences among means were significant only for $\mathrm{T}_{1}$ vs $\mathrm{T}_{4}, \mathrm{~T}_{5}$, or $\mathrm{T}_{6}$ (table 3 ).

$F$-values from the analysis of variance were significant (1\% level) for both milk and fat yields (table 1). The means and standard errors of the means for these traits are in table 2 . The five groups receiving supplement $\left(\mathrm{T}_{2}, \mathrm{~T}_{3}, \mathrm{~T}_{4}, \mathrm{~T}_{5}, \mathrm{~T}_{6}\right)$ had significantly higher milk and fat yields than cows on grazing alone $\left(\mathrm{T}_{1}\right)$ (table 3$) 0$. Those on a high level of concentrate feeding $\left(\mathrm{T}_{4}\right)$ averaged significantly higher yields than cows receiving molasses $\left(\mathrm{T}_{2}\right)$, corn $\left(\mathrm{T}_{3}\right)$, or urea + molasses $\left(\mathrm{T}_{6}\right)$. On limited concentrate feeding $\left(\mathrm{T}_{5}\right)$, the cows averaged significantly higher in yields than on molasses $\left(\mathrm{T}_{2}\right)$ or corn $\left(\mathrm{T}_{3}\right)$, but not significantly higher than cows receiving urea + molasses $\left(\mathrm{T}_{6}\right)$.

The highest milk yield per lactation for $\mathrm{T}_{1}$ cows was 10,323 lb, which was similar to that for $\mathrm{T}_{2}, 10,349 \mathrm{lb}$, and $\mathrm{T}_{3}, 10,410 \mathrm{lb}$. The lowest yield for $\mathrm{T}_{1}$ was $2,876 \mathrm{lb}$, and $20 \%$ of the lactations were less than 5,000 lb. The proportion of cows with yields of less than $5,000 \mathrm{lb}$ on the other treatments ranged from zero for $\mathrm{T}_{4}$ and $\mathrm{T}_{5}$ to $5 \%$ for $\mathrm{T}_{2}, \mathrm{~T}_{3}$, and $\mathrm{T}_{6}$ cows. The 
TABLE 2.-Means and standard errors of the means for various measures of performance by treatment groups

\begin{tabular}{|c|c|c|c|c|c|c|c|c|c|c|c|c|c|c|c|c|c|c|}
\hline & \multicolumn{3}{|c|}{$\mathrm{T}_{1}$} & \multicolumn{3}{|c|}{$\mathrm{T}_{2}$} & \multicolumn{3}{|c|}{$\mathrm{T}_{3}$} & \multicolumn{3}{|c|}{$\mathrm{T}_{4}$} & \multicolumn{3}{|c|}{$\mathrm{T}_{5}$} & \multicolumn{3}{|c|}{$\mathrm{T}_{6}$} \\
\hline Cows (No.) & 59 & & & 52 & & & 29 & & & 60 & & & 56 & & & 26 & & \\
\hline Total calvings & 98 & & & 80 & & & 50 & & & 83 & & & 93 & & & 29 & & \\
\hline Records (No.) & 87 & & & 73 & & & 48 & & & 79 & & & 76 & & & 26 & & \\
\hline Lactation length (days) & 271 & \pm & 4.7 & 284 & \pm & 3.2 & 281 & \pm & 4.2 & 291 & \pm & 2.4 & 290 & \pm & 2.2 & 290 & \pm & 3.6 \\
\hline$\%$ Lactation $<300$ days & 44.3 & & & 36.6 & & & 43.8 & & & 21.0 & & & 30.2 & & & 30.8 & & \\
\hline Milk yield (lb) & 6912 & \pm 1 & & 8005 & \pm & 159 & 8080 & \pm & 223 & 9861 & \pm & 248 & 9300 & & 194 & 8424 & & 337 \\
\hline Fat yield (lb) & 245 & \pm & 6.5 & 275 & \pm & 6.2 & 284 & \pm & 8.7 & 335 & \pm & 8.3 & 315 & \pm & 6.4 & 286 & \pm & 11.6 \\
\hline Supplement (lb) & 0 & & & 1162 & & & 1307 & & & 4537 & & & 1843 & & & 1226 & & \\
\hline \multicolumn{19}{|l|}{ Body weight (lb) } \\
\hline Initial & 1132 & \pm & 12.7 & 1144 & \pm & 15.6 & 1164 & \pm & 20.0 & 1185 & \pm & 41.0 & 1181 & \pm & 11.5 & 1231 & \pm & 24.2 \\
\hline Final & 1104 & \pm & 10.9 & 1152 & \pm & 15.0 & 1157 & \pm & 17.0 & 1198 & \pm & 12.6 & 1164 & \pm & 11.1 & 1182 & \pm & 21.4 \\
\hline Gain & -28 & \pm & 9.4 & 8 & \pm & 10.9 & -6 & \pm & 17.1 & 13 & \pm & 37.8 & -17 & \pm & 10.4 & -49 & \pm & 19.3 \\
\hline \multicolumn{19}{|l|}{ Days } \\
\hline Calving first heat & 60 & \pm & 3.6 & 52 & \pm & 4.1 & 49 & \pm & 3.4 & 57 & \pm & 4.4 & 52 & \pm & 3.7 & 50 & \pm & 13.5 \\
\hline First breeding to conception & 55 & \pm & 7.5 & 36 & \pm & 7.0 & 59 & \pm & 15.8 & 59 & \pm & 8.9 & 39 & \pm & 6.2 & 30 & \pm & 9.7 \\
\hline Services/conception & 2.4 & \pm & .19 & 1.9 & \pm & .14 & 2.1 & \pm & .26 & 2.5 & \pm & .20 & 2.2 & \pm & .18 & 1.7 & \pm & .22 \\
\hline Calving interval & 407 & \pm & 6.4 & 392 & \pm & 6.4 & 392 & \pm & 7.2 & 409 & \pm & 7.2 & 394 & \pm & 6.9 & 387 & \pm & 9.7 \\
\hline
\end{tabular}


TABLE 3.-Comparison of differences among treatment groups by procedure of Scheffe (15) for various traits

\begin{tabular}{|c|c|c|c|c|c|c|c|c|c|c|c|c|}
\hline \multirow{2}{*}{\multicolumn{2}{|c|}{$\begin{array}{l}\text { Treat- } \\
\text { ment } \\
\text { codes }\end{array}$}} & \multirow{2}{*}{$\begin{array}{l}\text { Lacta- } \\
\text { tion } \\
\text { length }\end{array}$} & \multicolumn{2}{|c|}{ Yield } & \multirow[b]{2}{*}{ Fat } & \multicolumn{3}{|c|}{ Body weight } & \multirow{2}{*}{$\begin{array}{l}\text { Calv- } \\
\text { ing to } \\
\text { first } \\
\text { heat }\end{array}$} & \multirow{2}{*}{$\begin{array}{l}\text { First } \\
\text { breed- } \\
\text { ing to } \\
\text { concep- } \\
\text { tion }\end{array}$} & \multirow{2}{*}{$\begin{array}{l}\text { Calv- } \\
\text { ing in- } \\
\text { terval }\end{array}$} & \multirow{2}{*}{$\begin{array}{c}\text { Serv- } \\
\text { ices/ } \\
\text { concep } \\
\text { tion }\end{array}$} \\
\hline & & & Milk & Fat & & $\begin{array}{l}\text { Ini- } \\
\text { tial }\end{array}$ & Final & Gain & & & & \\
\hline & & Days & $L b$ & $L b$ & $\%$ & $L b$ & $L b$ & $L b$ & Days & Days & Days & \\
\hline $\mathrm{T}_{1}$ & $\mathrm{~T}_{2}$ & 13 & $1093^{*}$ & 30 & .13 & 13 & 49 & 36 & 8 & 19 & 14 & .49 \\
\hline $\mathrm{T}_{1}$ & $\mathrm{~T}_{3}$ & 10 & $1167^{*}$ & $40 *$ & .03 & 32 & 53 & 21 & 11. & 4 & 15 & .32 \\
\hline $\mathrm{T}_{1}$ & $\mathrm{~T}_{4}$ & $21^{*}$ & $2949 *$ & $90^{\circ}$ & 13 & 53 & $94 *$ & 41 & 3 & 4 & 3 & .08 \\
\hline$T_{1}$ & $\mathrm{~T}_{5}$ & $30^{*}$ & $2388^{*}$ & $70^{*}$ & .16 & 52 & $62^{*}$ & 9 & 8 & 16 & 13 & .18 \\
\hline $\mathrm{T}_{1}$ & $\mathrm{~T}_{6}$ & $29^{*}$ & $1511 *$ & 41 & 16 & 99 & 77 & 22 & 10 & 15 & 20 & .70 \\
\hline $\mathrm{T}_{2}$ & $\mathrm{~T}_{3}$ & 3 & 75 & 3 & .09 & 18 & 4 & 15 & 2 & 23 & 0 & .17 \\
\hline $\mathrm{T}_{2}$ & $\mathrm{~T}_{4}$ & 7 & $1856^{*}$ & $60^{*}$ & .01 & 40 & 45 & 5 & 5 & 23 & 17 & .57 \\
\hline $\mathrm{T}_{2}$ & $\mathrm{~T}_{5}$ & 6 & $1295^{*}$ & $40^{*}$ & .02 & 39 & 12 & 27 & 0 & 3 & 1 & .31 \\
\hline $\mathrm{T}_{2}$ & $\mathrm{~T}_{6}$ & 6 & 418 & 11 & .02 & 86 & 28 & 58 & 2 & 6 & 5 & .22 \\
\hline $\mathrm{T}_{3}$ & $\mathrm{~T}_{4}$ & 10 & $1781^{*}$ & $51^{*}$ & .10 & 21 & 41 & 20 & 8 & I & 17 & .40 \\
\hline $\mathrm{T}_{3}$ & $\mathrm{~T}_{5}$ & 10 & $1220^{*}$ & 31 & .12 & 21 & 9 & 12 & 3 & 20 & 2 & .14 \\
\hline $\mathrm{T}_{3}$ & $\mathrm{~T}_{6}$ & 9 & 344 & 2 & .12 & 67 & 25 & 43 & 1 & 29 & 5 & .41 \\
\hline $\mathrm{T}_{4}$ & $\mathrm{~T}_{5}$ & 1 & 561 & 20 & .02 & 1 & 32 & 32 & 5 & 20 & 15 & .26 \\
\hline $\mathrm{T}_{4}$ & $\mathrm{~T}_{6}$ & 1 & $1438^{*}$ & $49^{*}$ & .02 & 46 & 17 & 63 & 7 & 29 & 22 & .84 \\
\hline $\mathrm{T}_{5}$ & $\mathrm{~T}_{6}$ & 0 & 876 & 29 & .00 & 47 & 16 & 31 & 2 & 9 & 7 & .51 \\
\hline
\end{tabular}

${ }^{1} 5 \%$ level.

higher proportion of low producers for $T_{1}$ was attributed to variations in the dry matter, crude protein, and digestibility of the forages (13).

The average milk yield for $\mathrm{T}_{1}$ cows was slightly higher (average 6,738 $\mathrm{lb}$ for 44 lactations) than other experiments on grazing in Puerto Rico (5, 19), similar to that for 16 Holsteins (7,063 lb) in Australia (17), but much higher than for several other experiments $(9,18,20)$. The average yield for molasses supplement $\left(\mathrm{T}_{2}\right)$ was much higher than obtained by Vohnout et al. (20). The yields for $\mathrm{T}_{6}$ cows were similar to that obtained by Thurbon et al. (17), using a supplement of biuret and molasses at a higher level of feeding.

\section{FAT PERCENTAGE}

Treatment effects were not significant for fat percentage (table 1); however, there was a tendency for fat percent to parallel the level of feeding (table 2). The multiple comparison analysis showed that none of the differences among means were significant (table 3 ). The level of fat percent for $T_{1}$ cows was similar to that reported from a previous study for grazing in Puerto Rico (19). The small change in fat percent with supplementary feeding in the current study differs from observations in Australia. Holsteins averaged $3.83 \%$ on grazing alone and $3.33 \%$ on grazing plus concentrates (17). Other studies in Australia $(8,9,16)$ showed a corresponding decline in fat percentage for Jerseys and Guern- 
seys when receiving supplement. Temperature conditions in Puerto Rico are considerably higher than in Australia, which probably caused a depression in fat test (1) that was more apparent for $T_{1}$ cows than the other groups.

\section{BODY WEIGHT}

Differences in the average initial weight among the groups were nonsignificant (tables 1 and 3). Treatment effects were significant at the $5 \%$ level for final weight (table 1 ). Cows on $\mathrm{T}_{1}$ were significantly lower in final weight than $T_{4}$ and $T_{5}$ cows (table 3 ). The average gains in body weight were slightly negative or positive (table 2 ). The small changes in weight for cows on $\mathrm{T}_{2}, \mathrm{~T}_{3}, \mathrm{~T}_{5}$, and $\mathrm{T}_{6}$ indicate the supplementary feeding was used largely for production or to satisfy maintenance requirements. The low level of gain on $\mathrm{T}_{4}$, without a significant increase in milk yield over restricted concentrate feeding $\left(\mathrm{T}_{5}\right)$, is unexpected. This suggests the consumption of forage by $\mathrm{T}_{4}$ cows was low; therefore, high levels of supplementary feeding are not recommended when cows have ample opportunity for grazing.

In most other studies, both with and without supplement, average daily gains have been 0.2 to $0.3 \mathrm{lb}$ resulting in 50 to $100 \mathrm{lb}$ gain for the lactation period $(3,4,5,6,9,10,14,19)$. The cause for the low changes in weight in the present experiment is not clear. The initial body weights were taken on the day of calving. No doubt the cows experienced further losses in weight during the early stages of lactation. If the initial weight had been taken later, the changes in weight for the lactation may have more nearly paralleled those reported by others. This point is undergoing further investigation.

\section{BREEDING EFFICIENCY}

Days from parturition to first observed estrus, time from first breeding to conception, services for conception, and calving interval were used to assess variation among groups in breeding efficiency. The $F$ values for treatment effects were nonsignificant (table 1). The magnitude of the error mean square (table 1) and that of the standard errors of the means (table 2) indicate high variability within group for all measures. Even so, certain trends are apparent. Cows on medium levels of supplement $\left(\mathrm{T}_{2}, \mathrm{~T}_{3}, \mathrm{~T}_{5}, \mathrm{~T}_{6}\right)$ returned to estrus sooner than cows on grazing alone $\left(\mathrm{T}_{1}\right)$ or a high level of supplement $\left(\mathrm{T}_{4}\right)$. However, in time from first breeding to conception and services per conception there was no discernible trend associated with treatment. Calving interval followed the same pattern as for time of calving to first observed estrus. The calving interval for all groups fell within the range for similar studies in both temperate and tropical areas $(14,19)$. Cows on $\mathrm{T}_{1}$ aver- 
aged 136 days dry, thus, their breeding efficiency would cause lower economic returns than if their calving interval equalled that for $\mathrm{T}_{2}, \mathrm{~T}_{3}$, $\mathrm{T}_{5}$, and $\mathrm{T}_{6}$. Cows on $\mathrm{T}_{4}$ averaged 118 days dry when lactations were terminated at 300 days, but the economic losses would not have been as high as for $\mathrm{T}_{1}$ since most $\mathrm{T}_{4}$ cows could have been milked profitably another 30 to 50 days.

The percentages culled for sterility (not pregnant by 300 days postpartum) were $11.2,8.3,7.0,7.6,6.0$, and 8.7 for $\mathrm{T}_{1}, \mathrm{~T}_{2}, \mathrm{~T}_{3}, \mathrm{~T}_{4}, \mathrm{~T}_{5}$, and $\mathrm{T}_{6}$, respectively. The higher proportion for $T_{1}$ suggests that lack of feed energy in the early months of lactation did interfere with breeding efficiency and that the number of replacements needed would be higher for a herd on grazing alone.

\section{HEALTH PROBLEMS}

The frequency of treatment for one or more health problems was similar for all treatments $-48,44,45,49,40$, and $46 \%$ for $\mathrm{T}_{1}, \mathrm{~T}_{2}, \mathrm{~T}_{3}, \mathrm{~T}_{4}$, $\mathrm{T}_{5}$, and $\mathrm{T}_{6}$, respectively. Treatments included mastitis based on bimonthly bacteriological examinations, foot problems, reproductive disorders, and miscellaneous causes, such as ketosis. Foot problems, resulting from abrasions caused by walking on roadways to and from pastures or foot rot, were the main cause for abnormal records and loss of cows on all treatments. The proportion of cows lost for health problems was $3.1 \%$ higher in the $\mathrm{T}_{1}$ group which suggests some relationship between level of feeding and breakdown in health. The $\mathrm{T}_{1}$ group also had the highest percentage ( 8.2 vs. 0 to 3.7$)$ culled for low production (less than $700 \mathrm{lb}$ for the first 30 days of lactation), especially among heifers.

\section{VALUE OF SUPPLEMENT}

Although researchers in both temperate and tropical areas $(3,4,5,6$, $7,8,9,14,18$ ) contend supplementary feeding of lactating cows grazing high quality pastures would not be profitable irrespective of amount, results from the current study show that supplementation could be economically feasible in many areas. Based on the means (table 2), lactation yields for $\mathrm{T}_{2}, \mathrm{~T}_{3}, \mathrm{~T}_{4}, \mathrm{~T}_{5}$, and $\mathrm{T}_{6}$ would be 15.8, 16.9, 42.7, 34.5, and $21.9 \%$, respectively, above that for grazing alone $\left(\mathrm{T}_{1}\right)$. After subtracting the value of milk from $\mathrm{T}_{1}$, plus the cost of each kind of supplement, the expected net return per cow per lactation would range from $\$ 20$ to $\$ 163$ (table 4). The estimated returns over $\mathrm{T}_{1}$ do not include consideration of depreciation on a higher capital investment required to store feed and feeding equipment nor labor to get the feed to the cows, but increased returns from the higher output per cow should more than 
offset these costs, particularly for $T_{2}, T_{3}, T_{5}$, and $T_{6}$ regimes. The fact that fewer cows would need to be milked to produce similar amounts of milk was not considered either, but certainly labor saved by milking 20 to $40 \%$ fewer cows would afford further economic advantages for the use of molasses, urea + molasses, corn, or limited feeding of concentrates.

Since there were differences in calving interval among feeding regimes (table 2) that could be of economic significance, milk yields were adjusted for calving interval to give an expected milk yield per cow per year (table 4). On the adjusted basis the advantages for regimes $T_{2}, T_{3}$, $\mathrm{T}_{4}, \mathrm{~T}_{5}$, and $\mathrm{T}_{6}$ over grazing become $20.2,21.4,42.0,39.0$, and $33.3 \%$,

TABLE 4.-Projected economic returns for supplementary feeding on the basis of lactation yield and milk yield per cow per year

\begin{tabular}{|c|c|c|c|c|c|c|}
\hline Item & $\mathrm{T}_{1}$ & $\mathrm{~T}_{2}$ & $\mathrm{~T}_{3}$ & $\mathrm{~T}_{4}$ & $\mathrm{~T}_{5}$ & $\mathrm{~T}_{6}$ \\
\hline & \multicolumn{6}{|c|}{ Per Lactation } \\
\hline Milk per lactation (lb) & 6912 & 8005 & 8080 & 9861 & 9300 & 8424 \\
\hline Value of milk (dollars) & 899 & 1040 & 1050 & 1282 & 1209 & 1095 \\
\hline \multirow{2}{*}{$\begin{array}{l}\text { Return (dollars) over } \mathrm{T}_{1} \text { less cost of } \\
\text { supplement }{ }^{2}\end{array}$} & & 104 & 60 & 20 & 163 & 146 \\
\hline & \multicolumn{6}{|c|}{ Per Cow/Year } \\
\hline Milk yield/year $(\mathrm{lb})^{3}$ & 6199 & 7453 & 7523 & 8800 & 8615 & 8265 \\
\hline Value of milk (dollars) ${ }^{1}$ & 806 & 969 & 978 & 1144 & 1120 & 1074 \\
\hline $\begin{array}{l}\text { Return (dollars) over } T_{1} \text { less cost of } \\
\text { supplement }(+ \text { or }-)^{3}\end{array}$ & & 126 & 81 & -25 & 167 & 218 \\
\hline
\end{tabular}

${ }^{1}$ Farm price of milk at $28 \mathrm{e} / \mathrm{qt}$ or $\$ 0.13 / \mathrm{lb}$.

2 Values for supplement: $37 \mathrm{c} / \mathrm{gal}$ for molasses $(\$ 0.032 / \mathrm{lb}) ; 48 \mathrm{e} / \mathrm{gal}$ for urea + molasses $(\$ 0.041 / \mathrm{lb}) ; \$ 7.00 \mathrm{cwt}$ for cow; and $\$ 8.00 \mathrm{cwt}$ for concentrates.

${ }^{3}$ Milk yield per lactation adjusted to yearly basis as ratio of average calving interval (days) to 365 days.

respectively, resulting in higher net returns for cows on $\mathrm{T}_{2}, \mathrm{~T}_{3}, \mathrm{~T}_{5}$, or $\mathrm{T}_{6}$. Because of above average calving intervals, the returns for $T_{1}$ and $T_{4}$ declined. If the higher rate of cow losses for $\mathrm{T}_{1}$, which would have meant a higher proportion of replacements per year, had been included, the merits of supplying additional nutrients in supplementary feeding would have been greater for all regimes and even offset the loss of $\$ 25$ for $\mathrm{T}_{4}$ cows (table 4).

As found by Donker et al. (5), a high level of supplementary feeding, such as that used for cows on $\mathrm{T}_{4}$, is marginal from the standpoint of economics, especially if breeding efficiency is poor. The returns for $\mathrm{T}_{6}$ over $T_{1}$ (table 4) appear to be good, but the advantage of $T_{6}$ may be inflated because of the number of cows involved. On the other hand, it seems that urea + molasses would be recommended over straight molasses or corn since the feeding of corn or molasses may cause a restriction of protein intake for lactating cows. From the standpoint of ease of 
handling and versatility in the use of locally available byproducts, the use of concentrates on a limited scale, like $T_{5}$, has merit.

Clearly, cows receiving additional energy responded favorably in performance, but the study did not provide insight into the most efficient system for supplementation to balance the nutrient needs for cows grazing highly fertilized pastures. If the limiting nutrient or nutrients from grazing could be identified, much greater response could possibly be achieved. The considerably higher milk yield for cows on limited concentrate feeding $\left(\mathrm{T}_{5}\right)$ over that for molasses $\left(\mathrm{T}_{2}\right)$ or corn $\left(\mathrm{T}_{3}\right)$ suggests the concentrate contained some nutrient that was limiting, most likely protein. The concentrate ration was pelleted which could have reduced protein solubility in the rumen resulting in less ammonia production in the rumen, thus, more protein passing to the lower tract. According to laboratory analysis (13) the pasture grasses were high in soluble protein but possibly a high proportion of this was lost as ammonia before it could be converted to microbial protein. The reason for little response from adding urea to molasses $\left(\mathrm{T}_{6}\right)$ may be that most urea was lost from the rumen. The results from this study, as well as numerous others, show a need for closer study of the metabolic picture, particularly for cows in the early months of lactation, on grazing and grazing plus supplement. The low response in milk yield and reduced breeding efficiency on high level of supplementary feeding $\left(\mathrm{T}_{4}\right)$ also lends support to the hypothesis that further investigations are required on the utilization of nutrients where grazing is used.

\section{RESUMEN}

Doscientas ochenta y dos vacas completaron una o más lactancias en pastoreo exclusivo $\left(\mathrm{T}_{1}\right) ;$ o pastoreo más suplementos de miel $\left(\mathrm{T}_{2}\right)$, maíz molido $\left(\mathrm{T}_{3}\right)$, concentrado comercial abundante $\left(\mathrm{T}_{4}\right)$, concentrado comercial suficiente $\left(\mathrm{T}_{5}\right)$ y urea más miel $\left(\mathrm{T}_{6}\right)$. La suplementación para los tratamientos $\mathrm{T}_{2}, \mathrm{~T}_{3}, \mathrm{~T}_{5}$ y $\mathrm{T}_{6}$ se ofreció a razón de una libra por cada dos libras de leche producida en exceso de 22 libras por día y para el tratamiento $T_{4}$ a razón de una libra de concentrado por cada dos libras de leche producida, independientemente del volumen de producción. En todos los grupos cada vaca pastó una cuerda de pastos de Estrella, Pangola o Guinea bien abonados, en una región húmeda de Puerto Rico. Mientras las vacas estaban secas sólo se alimentaron de pastoreo. El nacimiento de los becerros ocurrió durante el período de octubre de 1969 a febrero de 1974 . Tanto la temperatura como la lluvia fueron adecuadas para el crecimiento normal de las yerbas durante todo el año. La producción media de leche y grasa, basada en los registros adjustados de nacimiento para edad y mes, fue: 6,912 y $245 ; 8,005$ y $275 ; 8,080$ y $284 ; 9,861$ y $335 ; 9,300$ y 315 , y 8,424 y 286 libras para los tratamientos $\mathrm{T}_{1}, \mathrm{~T}_{2}, \mathrm{~T}_{3}, \mathrm{~T}_{4}, \mathrm{~T}_{5}$ y $\mathrm{T}_{6}$, respectivamente. Los efectos para tratamientos fueron significativos al nivel del $5 \%$ para duración de la lactancia, producción de leche y grasa y peso corporal final, pero no significativo para el porcentaje de grasa, aumento de peso o medidas de eficiencia en cruces de animales. Los pesos medios de los animales sometidos a los distintos tratamientos no difirieron significativamente.

La eficiencia en cruzamientos en cuanto a intervalos entre el parto y el primer estro y entre partos fue menor que el promedio en pastoreo exclusivo $\left(T_{1}\right)$ y que en suplemento alto $\left(\mathrm{T}_{4}\right)$. Cuando se adjustaron las producciones de leche a producciones esperadas por vaca por año, las ganancias sobre pastoreo solo fueron $20.2,21.4,42.0,39.0$ y $33.3 \%$ para 
los tratamientos $\mathrm{T}_{2}, \mathrm{~T}_{3}, \mathrm{~T}_{4}, \mathrm{~T}_{5}$ y $\mathrm{T}_{6}$, respectivamente. De estos resultados se determina que, los niveles medianos, pero no los altos, de alimentación suplementaria en vacas en producción y consumiendo forrajes tropicales de alto valor nutritivo son económicamente factibles.

\section{LITERATURE CITED}

1. Camoens, J. K., Environmental and genetic factors influencing the performance of Holsteins in a tropical climate, Ph.D Thesis, Cornell Univ., 1974.

2. - McDowell, R. E., VanVleck, L. D., Drosdoff, M., Miller, P. D., Ufford, G. R., y Rivera-Anaya, J. D., Factores para ajustar los registros de produccion de vacas Holstein en Puerto Rico, según la edad del animal y el mes de nacimiento, Est. Exp. Agr. Univ. P.R. Publ. 99, 1976.

3. Caro-Costas, R., and Vicente-Chandler, J., Milk production with all-grass rations from steep, intensively managed tropical pastures, J. Agr. Univ. P.R., 53: 251-8, 1969.

4. Dirven, J. G. P., Milk production on grassland in Surinam, Proc. II Inter. Grassland Congr., 269 (Abstr.), 1965.

5. Donker, J. D., Marten, G. C., and Wedin, W. R., Effect of concentrate level on milk production of cattle grazing high-quality pasture, J. Dairy Sci., 51: 67-73, 1968.

6. Dowden, D. R., and Seath, D. M., Grain feeding on pasture does not pay, J. Dairy Sci., 40: 613 (Abstr.), 1957.

7. Hamilton, R. I., Lambourne, L. J., Roe, R., and Minson, D. J., Quality of tropical grasses for milk production, Proc. XI Inter. Grassland Congr., 860-4, 1970.

8. Holder, J. M., Milk production from tropical pastures, Trop. Grasslands, 1: 135-41, 1967.

9. Jeffery, H. J., Coleman, R. L., Dale, A. B., and Holder, J. M., Milk production from unimproved and an improved grazing system with and without a grain supplement, Proc. Australian Soc. Anim. Prod., 8: 476-81,.1970.

10. McCullough, M. E., and Sell, O. E., The feeding value of excellent forage for milk production, J. Dairy Sci, 38: 1023-7, 1955.

11. McDaniel, B. T., Miller, R. H., and Corley, E. C., DHIA factors for projecting incomplete records to 305 days, Dairy Herd Impr. Letter, ARS, USDA, 44-164, 1965.

12. McDowell, R. E., and Hernández-Urdaneta, A., Intensive systems for beef production in the tropics, J. Anim. Sci. 41: (4): 1228-37, 1975.

13. - Cestero, H., Rivera-Anaya, J. D., Román-García, F., Arroyo-Aguilú, J. A., Berrocal, C. M., Soldevila, M., López-Alberty, J. C., and Metz, S. W., Tropical grass pastures with and without supplement for lactating cows in Puerto Rico, Agr. Exp. Sta. Univ. P.R. Bull. 238, 1975.

14. Moss, R. J., Suckling in Friesian cows grazing tropical pastures, Proc. III World Conf. Anim. Prod., 1: 2(a)-25-2(a)-27, 1973.

15. Scheffe, J., The Analysis of Variance, John Wiley \& Sons, New York, N.Y., 1959.

16. Stobbs, T. H., Production and composition of milk from cows grazing Siaratro (Phaseolus atropurpureus) and greenleaf Desmodium (Desmodium intortus), Australian J. Agr. Anim. Husb., 11: 268-73, 1971.

17. Thurbon, P. N., Chambers, G. A., Sibbick, R., and Stokoe, J., Progress report on milk production from cons grazing irrigated, fertilized Digitaria decumbens as influenced by stockin, rate and a molasses/biuret supplement, Proc. III World Conf. Anim. Prod., 1: ?(b)- $22-2$ (b)-14, 19.3.

18. Veita, J., Milk production of Holstein $\times$ Brahman cows given free access to elephant 
grass forage and either a high protein concentrate, molasses, or molasses/urea, Rev. Cubana. Cien. Agri., 5: 171-4, 1971.

19. Vicente-Chandler, J., Abruña, F., Caro-Costas, R., Figarella, J., Silva, S., and Pearson, R. W., Intensive grassland management in the humid tropics of Puerto Rico, Agr. Exp. Sta. Univ. P.R. Bull. 233, 164 pp, 1974.

20. Vohnout, K., Bateman, J. V., Beaudouin, J., and Félix, A., Effects of molasses on grass consumption and milk production of dairy cows in tropical areas, Proc. II World Conf. Anim. Prod., 397-8 (Abstr.), 1969. 